${ }^{\text {I }}$ Universidade de São Paulo, Programa de Pós-Graduação

em Antropologia Social, Brasil

irisaraujo8o@yahoo.com.br

Íris Morais Araújo'

\title{
DOS KARITIANA E SUAS INQUIETAS COMPANHIAS
}

Inquietas companhias: sobre os animais de criação entre os Karitiana (2012).

Felipe Ferreira Vander Velden. São Paulo: Alameda, 357 p.

O livro que temos em mãos, originalmente monografia de doutorado defendida em 20 ıo na Unicamp, é uma bem-vinda contribuição que busca sanar algumas dívidas. A primeira delas é a de reduzir o débito que a Antropologia acumulou com as populações indígenas de onde atualmente é o Estado de Rondônia, que deixaram de causar o interesse da disciplina nas últimas décadas. Inquietas companhias tem o feito de ser a primeira tese sobre os Karitiana, uma população de 350 pessoas falante da língua de mesmo nome - o único idioma vivo da família Arikém do tronco Tupi - e concentrada principalmente em aldeias nos municípios de Porto Velho e Candeias do Jamari (RO).

Outra lacuna que o trabalho visa preencher tem a ver com a mirada original pela qual os Karitiana deixaram-se observar: por meio das relações que estabelece(ra)m com os assim chamados animais de criação cachorros, porcos, cavalos, galinhas -,com os quais passaram a conviver após o contato com os não indígenas. Felipe Ferreira Vander Velden persegue os desdobramentos de tal encontro, demonstrando, numa narrativa bem conduzida, a acomodação singular à qual os animais de criação foram submetidos nesse socius.

A etnografia, resultado de um ano de trabalho de campo, é apresentada em quatro capítulos. O antropólogo inicia sua análise debruçando-se sobre as formulações indígenas sobre o aparecimento desses animais. Ao contrário de outros grupos que enunciam a existência de tais seres como 
resultado da ação de seus demiurgos, ou, de modo independente, à instituição de relações com os não indígenas, os Karitiana os localizam sob o rastro dos contatos iniciais com os brancos - ocorridos quando a frente extrativista da borracha avançou sobre seu território, provavelmente em finais do século XIX.

A demarcação da origem externa ao mundo erguido por Botỹj, o criador do Universo, pode ser notada também na maneira com que alguns desses animais são chamados em Karitiana. Algumas espécies têm o termo opok, que se refere aos não indígenas, na composição de suas designações - como galinha (opok ako) ou boi (opok 'irip) -, reforçando assim o exotismo desses seres. O autor levantou ainda os nomes próprios desses animais, e destaca que, em sua maioria, remetem ao universo cultural não indígena, com emprego majoritário de palavras do português.

Vander Velden prossegue sua argumentação tentando compreender os motivos que levam os Karitiana a criar esses seres. Em seu trabalho de campo, encontrou animais de criação diversos, apanhados na mata (como jacamins, araras, periquitos, papagaios, tracajás, tartarugas, quatis, macacos e antas), ou de origem exógena ao ambiente amazônico (como cães, gatos, cavalos, burros, coelhos, porcos e galinhas). A explicação-chave para essa profusão é o prazer que os Karitiana sentem diante da presença desses animais. São enfeites da casa e da aldeia; servem, assim, principalmente à fruição estética. Os cães, porém, distinguem-se dessa formulação geral: ao mesmo tempo em que são valorizados pelos homens por ajudarem-nos em suas caçadas, os indígenas rechaçam seu comportamento considerado antissocial, por ser desordeiro e incestuoso.

Ademais, os Karitiana vêm demonstrando interesse em possuir animais fora das aldeias: praticariam assim a pecuária, a avicultura e a piscicultura. Contudo, as tentativas de criação de cabras e galinhas de granja, ocorridas em épocas anteriores à pesquisa, redundaram em fracasso. Os indígenas reclamam, sobretudo, da falta de apoio e de capacitação técnica - querem saber criar tais espécies como os fazendeiros o fazem. O antropólogo chama a atenção também para o estranhamento de seus interlocutores em relação ao comportamento adquirido pelos animais em confinamento, revelando uma ontologia que destaca, sobretudo, a agência desses seres diante de uma situação concebida como anômala. E não deixa de criticar a insistência das instituições parceiras dos indígenas em implementarem projetos comunitários, sendo que a unidade de criação de animais domésticos e de produção agrícola é a casa. Alerta, dessa maneira, para a falta de diálogo das agências promotoras desse tipo de iniciativa com as formas nativas de organização do trabalho e da produção.

Se os projetos não deram certo, todavia os seres criados parecem encantar os Karitiana que, querem além de tudo, com os mesmos conviver. O 
antropólogo retoma o foco no espaço aldeão de modo a destacar que os animais de criação participam plenamente da vida doméstica Karitiana, de modo que possuem um dono (ou uma casa) como referência. Ym'et, que pode ser traduzido tanto como "minha criação" quanto "meu filho", é o termo com o qual demarcam a relação com esses seres, e denota cuidado e controle. Os filhotes recebem muito zelo, especialmente, de mulheres e crianças: são alimentados na boca, deixados em cestos de palha no interior das casas, acariciados e jamais deixados nas aldeias quando da ausência de seus donos. A morte dos mesmos é sentida especialmente pelas mulheres, que se lamentam e choram o desaparecimento de suas criações. Os homens, por sua vez, possuídos pelo sentimento de raiva, juram vingança contra os algozes de seus companheiros, sejam eles bichos do mato ou, por vezes, os próprios parentes que se envolvem em agressões contra animais alheios.

Esse nexo filial, no entanto, está submetido à passagem do tempo. Os animais adultos merecem outro tratamento, no qual a regra é a violência. $\mathrm{O}$ autor testemunhou agressões a cachorros e gatos sem razão aparente e notou que "cachorros são quase todos esquálidos, famintos, sujos e sarnentos; gatos são ainda mais desprezados" (p.I85). E, mais ainda, que "cães doentes [...] são abandonados em seu sofrimento solitário até a morte, e animais desordeiros e agressivos podem ser baleados" (p.I85-186). A razão para essa conduta, segundo o antro- pólogo, é que, nessa fase da vida, "passam a receber tratamento condizente com sua maturidade, o que inclui autonomia e responsabilidade" (p.I86). Afinal, para os Karitiana, "tornar-se adulto é aprender a cuidar de si mesmo, provendo-se a si mesmo e a família, o que inclui necessariamente o convívio com [...] potências agressoras do mundo humano e não humano" (p.I87).

Após apresentar as práticas indígenas em relação aos animais de criação, o autor situa esses seres em uma grade de classificação Karitiana dos animais, demonstrando sua ambivalência. O autor demarca a diferença entre os seres que são concebidos como alimento (him, carne) e os considerados impróprios para o consumo (him sara, carne ruim); os que vivem no mato, são considerados bravos, parte do domínio masculino e que servem de alimento, e os que vivem na casa, são considerados mansos, parte do domínio feminino e que devem ser alimentados. Embora boa parte dos animais de criação (como os porcos e as galinhas) sejam him, em função de sua condição de ym'et nunca são consumidos pelas famílias que os alimentam.

Vander Velden finaliza seu estudo discutindo o lugar desses seres na escatologia Karitiana tal qual se apresenta nos dias de hoje, após o grupo se apropriar do cristianismo. Os indígenas ressaltam toda série de crueldades a que são acometidos os novatos no inferno, incluindo brigas com perus, galos, ovelhas, cabritos, vacas, cavalos, jumentos e porcos, todos maiores e mais agressivos do que 
aqueles que vivem nas aldeias. O caminho até o céu onde vive Botỹj não é menos fácil. Esse espaço é prenhe de animais de criação, igualmente mais fortes e hostis do que os da Terra, e agridem os humanos que, em vida, maltrataram suas criações. Apenas após passar por essa prova os Karitiana vão encontrar, ao lado do heroi criador, a eterna mocidade, com fartura, saúde e alegria.

Em Inquietas companhias, Felipe Ferreira Vander Velden convida, à guisa de conclusão, a uma reflexão a respeito das políticas públicas de assistência aos animais de criação - que, afinal, são sujeitos de direitos no país em contextos indígenas. Afinal, se a Antropologia vem se esforçando, em suas investigações, em tomar os não humanos "como entes com os quais os homens compartilham o mundo e sem os quais é impossível existir plenamente", é possível levar este tipo de estudo "para outro patamar, em que as ontologias não ocidentais [...] sejam, de fato, consideradas em toda sua complexidade" (p.319). O autor sugere uma abertura de um diálogo que, reconhecendo as ontologias diversas as quais informam as concepções e práticas ameríndias em relação aos animais de criação, possam resultar na adoção de acordos que permitam a realização de outras práticas em relação a essas inquietas companhias.

Recebida em 06/03/20I4 | Aprovada em 02/06/2014 
Íris Morais Araújo é doutora pelo Programa de PósGraduação em Antropologia Social da Universidade de São Paulo (USP). É graduada (2003) e licenciada (2004) em Ciências Sociais e mestre em Antropologia Social (2006) pela mesma universidade. Realizou estágio-sanduíche no Centre d'Enseignement et de Recherche en Ethnologie Amérindienne do Laboratoire d'Ethnologie et de Sociologie Comparative, instituição ligada à Université Paris X. É, ainda, pesquisadora do Centro de Estudos Ameríndios da USP e autora de Militão Augusto de Azevedo: fotografia, história e antropologia (2010). 